University of Vermont

UVM ScholarWorks

College of Agriculture and Life Sciences Faculty

Publications

College of Agriculture and Life Sciences

8-9-2019

\title{
Policy options to streamline the carbon market for agricultural nitrous oxide emissions
}

\author{
Meredith T. Niles \\ University of Vermont \\ Hannah Waterhouse \\ University of California, Davis \\ Robert Parkhurst \\ Sierra View Consulting \\ Eileen L. McLellan \\ Environmental Defense Fund \\ Sara Kroopf \\ Environmental Defense Fund
}

Follow this and additional works at: https://scholarworks.uvm.edu/calsfac

Part of the Agriculture Commons, Climate Commons, and the Sustainability Commons

\section{Recommended Citation}

Niles MT, Waterhouse H, Parkhurst R, McLellan EL, Kroopf S. Policy options to streamline the carbon market for agricultural nitrous oxide emissions. Climate Policy. 2019 Aug 9;19(7):893-907.

This Article is brought to you for free and open access by the College of Agriculture and Life Sciences at UVM ScholarWorks. It has been accepted for inclusion in College of Agriculture and Life Sciences Faculty Publications by an authorized administrator of UVM ScholarWorks. For more information, please contact scholarworks@uvm.edu. 


\title{
Climate Policy

\section{Policy options to streamline the carbon market for agricultural nitrous oxide emissions}

\author{
Meredith T. Niles, Hannah Waterhouse, Robert Parkhurst, Eileen L. McLellan \\ \& Sara Kroopf
}

To cite this article: Meredith T. Niles, Hannah Waterhouse, Robert Parkhurst, Eileen L. McLellan \& Sara Kroopf (2019) Policy options to streamline the carbon market for agricultural nitrous oxide emissions, Climate Policy, 19:7, 893-907, DOI: 10.1080/14693062.2019.1599802

To link to this article: https://doi.org/10.1080/14693062.2019.1599802
(C) 2019 The Author(s). Published by Informa UK Limited, trading as Taylor \& Francis Group

曲 Published online: 09 Apr 2019.

\section{$\sqrt{6}$ Submit your article to this journal $₫$}

Џlll Article views: 1765

Q View related articles $\sqsubset$

View Crossmark data $\asymp$

Citing articles: 5 View citing articles 


\title{
Policy options to streamline the carbon market for agricultural nitrous oxide emissions
}

\author{
Meredith T. Niles ${ }^{a}$, Hannah Waterhouse ${ }^{b}$, Robert Parkhurst ${ }^{c}$, Eileen L. McLellan ${ }^{d}$ and Sara Kroopf \\ ${ }^{\mathrm{a}}$ Food Systems Program, Department of Nutrition and Food Science, University of Vermont, Burlington, VT, USA; ${ }^{\mathrm{b}}$ Department of \\ Land, Air and Water Resources, University of California-Davis, Davis, CA, USA; 'Sierra View Consulting, Sierra Madre, CA, USA;

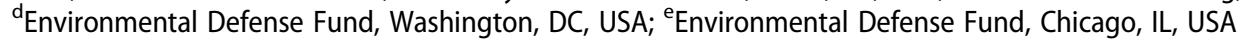

\begin{abstract}
The majority of emissions of nitrous oxide - a potent greenhouse gas (GHG) - are from agricultural sources, particularly nitrogen fertilizer applications. A growing focus on these emission sources has led to the development in the United States of GHG offset protocols that could enable payment to farmers for reducing fertilizer use or implementing other nitrogen management strategies. Despite the development of several protocols, the current regional scope is narrow, adoption by farmers is low, and policy implementation of protocols has a significant time lag. Here we utilize existing research and policy structures to propose an 'umbrella' approach for nitrogen management GHG emissions protocols that has the potential to streamline the policy implementation and acceptance of such protocols. We suggest that the umbrella protocol could set forth standard definitions common across multiple protocol options, and then modules could be further developed as scientific evidence advances. Modules could be developed for specific crops, regions, and practices. We identify a policy process that could facilitate this development in concert with emerging scientific research and conclude by acknowledging potential benefits and limitations of the approach.

\section{Key policy insights}

- Agricultural greenhouse gas market options are growing, but are still underutilized

- Streamlining protocol development through an umbrella process could enable quicker development of protocols across new crops, regions, and practices

- Effective protocol development must not compromise best available science and should follow a rigorous pathway to ensure appropriate implementation
\end{abstract}

\section{ARTICLE HISTORY}

Received 16 July 2018

Accepted 15 March 2019

\section{KEYWORDS}

GHG emissions; offset protocol; climate policy; agriculture; Nitrous Oxide

\section{Introduction}

Although nitrous oxide $\left(\mathrm{N}_{2} \mathrm{O}\right)$ results in less than seven percent of total global greenhouse gas (GHG) emissions (IPCC, 2014), it has a significant climate impact, with 310 times the atmospheric warming potential of carbon dioxide, and its impact is growing: $\mathrm{N}_{2} \mathrm{O}$ emissions have increased nine-fold over the last 50 years as a result of human activities (Rees, 2011; Smith et al., 2007). The majority of global $\mathrm{N}_{2} \mathrm{O}$ emissions come from agricultural sources (Reay et al., 2012). The United States (US) is the second largest emitter of $\mathrm{N}_{2} \mathrm{O}$ emissions globally, (World Bank, 2017), with 79\% of $\mathrm{N}_{2} \mathrm{O}$ emissions resulting from agricultural soil management (EPA, 2015), making farmers and agricultural systems an important target for $\mathrm{N}_{2} \mathrm{O}$ mitigation.

However, the diffuse nature of $\mathrm{N}_{2} \mathrm{O}$ emissions across agricultural fields, as well as their high degree of variability across climate, soil, and other local conditions (Henault, Grossel, Mary, Roussel, \& Leonard, 2012), makes

CONTACT Meredith T. Niles mtniles@uvm.edu $\Theta$ Food Systems Program, Department of Nutrition and Food Science, University of Vermont, 350 Carrigan Wing, 109 Carrigan Drive, Burlington, VT 05401, USA 
mitigation more challenging from a policy standpoint as compared to point-source emissions (e.g. energy, industrial and transportation sources; Niles \& Lubell, 2012). As a result, efforts to mitigate agricultural $\mathrm{N}_{2} \mathrm{O}$ emissions in the US have thus far largely been voluntary and incentive-based through government or private programmes. In response to the growing $\mathrm{N}_{2} \mathrm{O}$ emissions in agriculture, and the recognition that many farmers could apply significantly less nitrogen $(\mathrm{N})$ to their crops (especially corn) without compromising yield (e.g. Cassman, Dobermann, \& Walters, 2002), efforts in the mid-2000s began to identify how GHG offset markets could be established to reward farmers with payments for nitrogen rate reductions, which can result in $\mathrm{N}_{2} \mathrm{O}$ emission reductions (Millar, Robertson, Grace, Gehl, \& Hoben, 2010; Shcherbak, Millar, \& Robertson, 2014). Here we focus on the rise and implementation of agricultural offset protocols that have developed in the recent decade, particularly in the US, and propose a new approach that can potentially address multiple stakeholder goals while advancing the implementation and adoption of $\mathrm{N}_{2} \mathrm{O}$ protocols at a broader scale.

\subsection{Carbon offset protocol development}

To date in the US, six $\mathrm{N}_{2} \mathrm{O}$ emission reduction agricultural protocols (Table 1) have been developed based on existing quantification methodologies, all through a public process and all of which are publicly available. The protocols from the Climate Action Reserve and American Carbon Registry have each gone through an updating process where different models were used in the update. While only the most recent protocol can be used, it is important to note that the protocols are being updated to use the latest science and are being expanded to include additional crops. Each of these protocols thus have the capacity to pay farmers for their implementation of one or more protocol practices, if these are eligible within the given scope of a protocol. At the same time, there is growing political momentum for developing new offset protocols, most recently with the passage of AB-398 in California which includes provisions to encourage the California Air Resources Board to develop additional offset protocols. The California cap-and-trade programme currently includes six offset protocols, including two in agriculture, but none related to $\mathrm{N}_{2} \mathrm{O}$ emissions (ARB, 2017). There are critical tensions between multiple stakeholders, such as the business community, farmers, policymakers (including both protocol developers and local, state, or regional governments that may adopt these protocols), environmental and environmental justice advocates, and scientists that are involved in the development of offset protocols. The business community naturally seeks the ability to claim GHG reductions from offset generation as quickly as possible, while farmers seek practices that are easy and economically viable to implement. Policymakers, environmental advocates and scientists aim to advance emission reductions in a conservative manner, to ensure that emission reductions are independently verifiable and realistic, based on the best science and models available. Likewise, given that scientific understanding of the GHG impacts of a variety of crops and practices continues to advance over time, there is a lack of consensus about how to incorporate new scientific understanding and quantification methodologies into established protocols. All of these priorities are underpinned by a growing need to reduce emissions as quickly as possible to avoid future climate impacts. This is particularly relevant, since despite the existing number of protocols in agriculture, the actual number of farmers and projects that have participated in such programmes remains extremely low. ${ }^{1}$

To overcome the multiple challenges facing $\mathrm{N}_{2} \mathrm{O}$ protocol development- including competing stakeholder goals and needs, and the inherent desire to expand mitigation opportunities to additional crops and practices here we propose a new approach to $\mathrm{N}_{2} \mathrm{O}$ offset protocol development: an 'umbrella' protocol framework for $\mathrm{N}_{2} \mathrm{O}$ emissions reductions resulting from crop nitrogen management. An umbrella protocol would establish a basic set of requirements and details that are unlikely to change across crops, regions and management practices. The umbrella protocol can be supplemented with subsidiary modules for specific crops, locations and practices as appropriate field-level data and quantification tools become available. We recommend a set of science-based best practices and a process for developing subsidiary modules. Overall, we propose that the development of an umbrella protocol allows reconciliation of the multiple and seemingly conflicting goals inherent to different stakeholder groups -ease of use and adoption, timeliness, conservativeness, and scientific rigourand can help to streamline the additional creation- and most importantly, implementation and adoption of $\mathrm{N}_{2} \mathrm{O}$ agricultural offset protocols - throughout the US. 
Table 1. Existing agricultural $\mathrm{N}_{2} \mathrm{O}$ reduction protocols.

\begin{tabular}{|c|c|c|c|c|c|c|}
\hline $\begin{array}{l}\text { Protocol } \\
\text { Registry }\end{array}$ & Protocol Name & Protocol Developers & $\begin{array}{l}\text { Data for Model } \\
\text { Development }\end{array}$ & $\begin{array}{l}\text { Quantification } \\
\text { Methodology }\end{array}$ & $\begin{array}{c}\text { Applicable } \\
\text { Cropping System }\end{array}$ & Implementation \\
\hline $\begin{array}{l}\text { Voluntary } \\
\text { Carbon } \\
\text { Standard }\end{array}$ & $\begin{array}{l}\text { Quantifying } \mathrm{N}_{2} \mathrm{O} \\
\text { Emissions } \\
\text { Reductions in } \\
\text { Agricultural Crops } \\
\text { through Nitrogen } \\
\text { Fertilizer Rate } \\
\text { Reduction, } \mathrm{v} 1.1^{\mathrm{a}}\end{array}$ & $\begin{array}{l}\text { The Climate Group, } \\
\text { International } \\
\text { Emissions Trading } \\
\text { Association, World } \\
\text { Economic Forum, } \\
\text { World Business } \\
\text { Council for } \\
\text { Sustainable } \\
\text { Development }\end{array}$ & $\begin{array}{l}\text { 2008-2010, five } \\
\text { sites in } \\
\text { Michigan }\end{array}$ & $\begin{array}{l}\text { IPCC Tier } 1 \text { or } \\
\text { MSU-EPRI Tier } \\
2 \\
\text { Quantification } \\
\text { Methodology }\end{array}$ & Corn & $\begin{array}{l}\text { Approved by } \\
\text { board after } \\
\text { public comment } \\
\text { in } 2013 .\end{array}$ \\
\hline $\begin{array}{l}\text { Voluntary } \\
\text { Carbon } \\
\text { Standard }\end{array}$ & $\begin{array}{l}\text { Estimation of } \\
\text { Emissions of Non- } \\
\text { CO2 GHGs from } \\
\text { Soils }\end{array}$ & $\begin{array}{l}\text { The Earth Partners } \\
\text { LLC }\end{array}$ & $\begin{array}{l}\text { IPCC or Local } \\
\text { Calibration and } \\
\text { Validation of } \\
\text { DNDC }\end{array}$ & $\begin{array}{l}\text { IPCC Tier } 1 \text { or } \\
\text { DNDC Tier } 3\end{array}$ & Any & $\begin{array}{l}\text { Approved by } \\
\text { board after } \\
\text { public comment } \\
\text { in } 2012 .\end{array}$ \\
\hline $\begin{array}{l}\text { American } \\
\text { Carbon } \\
\text { Registry } \\
\text { Version } \\
1.0(2012)\end{array}$ & $\begin{array}{l}\text { Methodology for } \\
\text { Quantifying Nitrous } \\
\text { Oxide }\left(\mathrm{N}_{2} \mathrm{O}\right) \\
\text { Emissions } \\
\text { Reductions from } \\
\text { Reduced Use of } \\
\text { Nitrogen Fertilizer } \\
\text { on Agricultural } \\
\text { Crops }\end{array}$ & $\begin{array}{l}\text { Michigan State } \\
\text { University and the } \\
\text { Electric Power } \\
\text { Research Institute }\end{array}$ & $\begin{array}{l}\text { 2008-2010, five } \\
\text { sites in } \\
\text { Michigan }\end{array}$ & $\begin{array}{r}\text { MSU-EPRI Tier } 2 \\
\text { and IPCC Tier } 1\end{array}$ & Corn & $\begin{array}{l}\text { Approved by } \\
\text { Registry Board } \\
2012 \text { after } \\
\text { public } \\
\text { comment. }\end{array}$ \\
\hline $\begin{array}{l}\text { American } \\
\text { Carbon } \\
\text { Registry } \\
\text { Version } \\
2.0(2012)\end{array}$ & $\begin{array}{l}\text { Methodology for } \mathrm{N}_{2} \mathrm{O} \\
\text { Emissions } \\
\text { Reductions from } \\
\text { Changes in Fertilizer } \\
\text { Management }{ }^{c}\end{array}$ & $\begin{array}{l}\text { American Carbon } \\
\text { Registry }\end{array}$ & $\begin{array}{l}\text { 2009-2013 } \\
\text { Wisconsin, } \\
\text { lowa, Idaho, } \\
\text { and planned } \\
\text { expansion to } \\
\text { California }\end{array}$ & DNDC Tier 3 & $\begin{array}{l}\text { Corn, Soybean, } \\
\text { Wheat, } \\
\text { Sorghum, } \\
\text { Barley, } \\
\text { Tomatoes, } \\
\text { Cotton, Oats }\end{array}$ & $\begin{array}{l}\text { Approved by } \\
\text { Registry Board } \\
2014 \text { after } \\
\text { public } \\
\text { comment. }\end{array}$ \\
\hline $\begin{array}{l}\text { Climate } \\
\text { Action } \\
\text { Reserve } \\
\text { Version } \\
1.0^{\mathrm{d}}\end{array}$ & $\begin{array}{l}\text { Nitrogen } \\
\text { Management } \\
\text { Project Protocol }\end{array}$ & $\begin{array}{l}\text { Climate Action } \\
\text { Reserve }\end{array}$ & $\begin{array}{l}\text { 2008-2010, five } \\
\text { sites in } \\
\text { Michigan }\end{array}$ & $\begin{array}{c}\text { MSU-EPRI Tier } 2 \\
\text { Quantification } \\
\text { Methodology }\end{array}$ & $\begin{array}{l}\text { North Central } \\
\text { Region of the } \\
\text { USA and only } \\
\text { corn cropping } \\
\text { systems }\end{array}$ & $\begin{array}{l}\text { Approved by } \\
\text { Reserve Board } \\
2013 \text { after } \\
\text { public } \\
\text { comment. }\end{array}$ \\
\hline $\begin{array}{l}\text { Climate } \\
\text { Action } \\
\text { Reserve } \\
\text { Version } \\
2.0^{\mathrm{e}}\end{array}$ & $\begin{array}{l}\text { Nitrogen } \\
\text { Management } \\
\text { Project Protocol }\end{array}$ & $\begin{array}{l}\text { Climate Action } \\
\text { Reserve }\end{array}$ & $\begin{array}{l}13,900 \text { randomly } \\
\text { sampled } \\
\text { cropland } \\
\text { points from } \\
\text { the Midwest } \\
\text { and California }\end{array}$ & $\begin{array}{l}\text { DAYCENT used to } \\
\text { develop Tier } 2 \\
\text { emission } \\
\text { factors }\end{array}$ & $\begin{array}{l}\text { Barley, Corn, } \\
\text { Cotton, Oats, } \\
\text { Sorghum, } \\
\text { Wheat, and } \\
\text { Tomatoes - } \\
\text { regions specific } \\
\text { for each crop as } \\
\text { outlined in the } \\
\text { protocol }\end{array}$ & $\begin{array}{l}\text { Approvedy by } \\
\text { Reserve Board } \\
2018 \text { after } \\
\text { public } \\
\text { comment. }\end{array}$ \\
\hline
\end{tabular}

\footnotetext{
Verified Carbon Standard. Available: https://verra.org/methodology/vm0022-quantifying-n2o-emissions-reductions-in-agricultural-cropsthrough-nitrogen-fertilizer-rate-reduction-v1-1/

${ }^{b}$ American Carbon Registry. Available: https://americancarbonregistry.org/carbon-accounting/old/carbon-accounting/methodology-for-n2oemission-reductions-through-fertilizer-rate-reduction

cAmerican Carbon Registry. Available: https://americancarbonregistry.org/carbon-accounting/standards-methodologies/emissions-reductionsthrough-changes-in-fertilizer-management

${ }^{\mathrm{d} C l i m a t e}$ Action Reserve. Available: http://www.climateactionreserve.org/how/protocols/nitrogen-management/dev/\#ver_1

${ }^{\text {e}}$ Climate Action Reserve. Available: http://www.climateactionreserve.org/how/protocols/nitrogen-management/
}

\section{Methodology}

This framework development involved a comprehensive review of multiple streams of academic and policy research. First, a comprehensive review of the existing quantification methodologies was undertaken to examine the history, methodological approach, and application of existing standards, with a particular focus on recent work from Tonitto, Woodbury, and McLellan (2018). This was accompanied by an exploration of the literature utilizing these quantification methodologies, and their application into current policy systems. A review of existing carbon offset protocols relevant to agriculture and forestry was also conducted to 
enable understanding of the consistencies amongst protocols, leading to the development of concepts related to the umbrella protocol. Based on the integration of both the existing policy protocols and quantification methodologies and their relevant academic literature, we developed an umbrella framework to integrate the two.

In the following sections we present the proposed structure of our umbrella protocol, including the overall framework as well as the proposed subsidiary modules that would continue to be developed independently as new locations, practices and crops entered into a nitrogen protocol. We then detail the best practices for developing subsidiary modules, as informed by the scientific literature. We discuss the current and future opportunities for subsidiary modules, and conclude by discussing some other considerations that may be necessary for policymakers developing nitrogen management protocols, including issues related to farmer behaviour and participation. Throughout the manuscript we aim to integrate the best available technical science within the policy context, to provide pathways for policymakers to consider this work.

\section{An umbrella protocol: need and framework}

The traditional approach to developing offset protocols involves creating a new protocol for each combination of practice (e.g. nitrogen application reduction), crop (e.g. corn) and geography (e.g. California). This approach is onerous and time consuming. For example, the development and adoption of the Rice Cultivation Projects Compliance Offset Protocol by the California Air Resources Board took approximately two years. ${ }^{2}$ Currently, efforts to apply an existing protocol, such as the Climate Action Reserve protocol shown in Table 1 to projects in a new region beyond the scope of the current protocol, would require beginning the protocol development process over again from the beginning. We propose that the protocol development and approval process can be accelerated through the development of an umbrella protocol that encompasses one particular type of GHG or management activity (agricultural nitrogen management in the case of $\mathrm{N}_{2} \mathrm{O}$ emissions reductions), which can then be expanded to different crops, geographies and practice(s). An umbrella protocol is expected to reduce the time necessary for policy development, particularly within the California rulemaking process, as it can minimize the need for recreating sections of the protocol that are the same regardless of practice, crop and geography, while simultaneously ensuring both the ease of use and scientific rigour necessary for confident implementation.

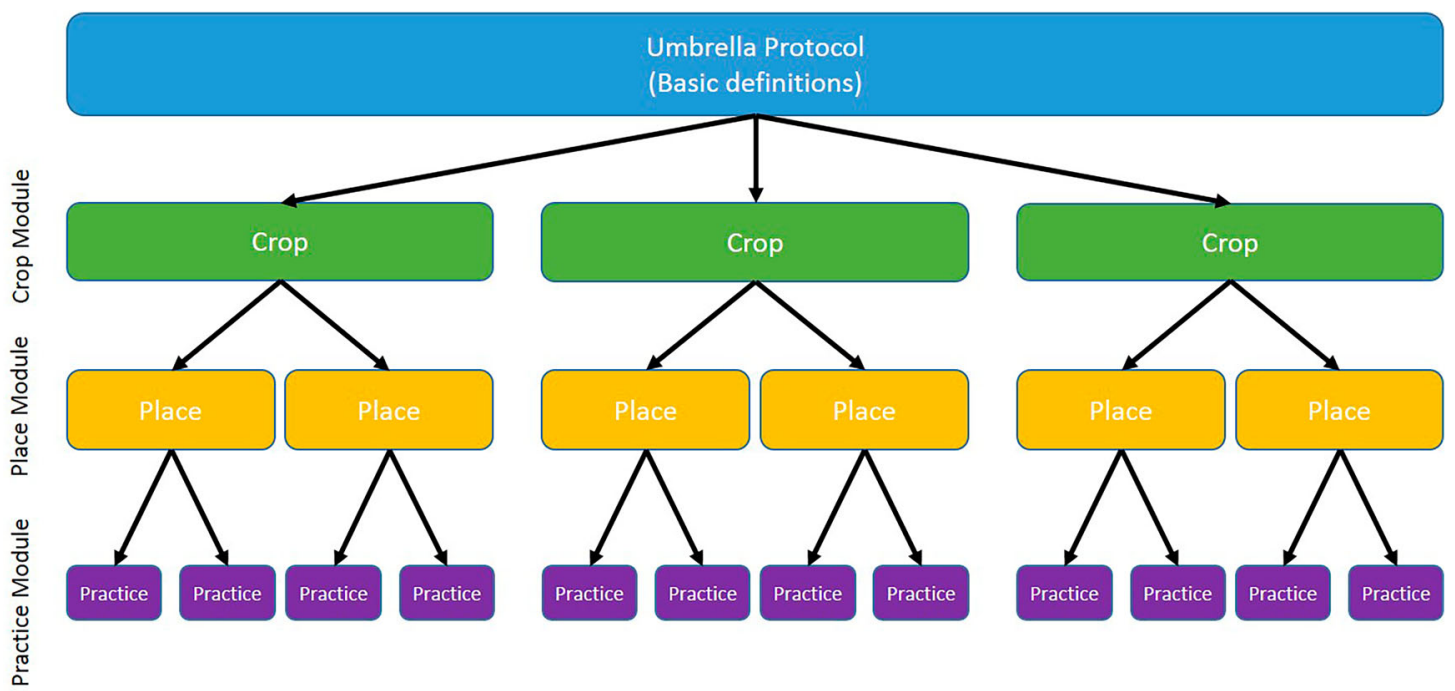

Figure 1. Umbrella Protocol Framework. Initially, an umbrella protocol could be developed with basic definitions relevant for all potential $\mathrm{N}_{2} \mathrm{O}$ emission practices related to nitrogen. Subsidiary modules could be developed for specific crops, and for specific places where those crops are grown. Further subsidiary modules could be developed for specific agricultural management practices used with specific crops at specific locations. 
Figure 1 illustrates the framework for the umbrella protocol. The overall framework seeks to build a scientifically-sound and streamlined approach to the process of regulatory or voluntary carbon registry approval of protocols and modules specific to new crop-location-practice combinations. The umbrella protocol would consist of a suite of definitions for those protocol components that are universal across crop, geography and/or management practices; this would allow subsidiary modules to be developed for specific crops, places and practices, without having to redefine these higher level definitions. Regulatory language and concepts in modules at lower levels of Figure 1 would build on previously-approved modules at higher levels, such that the entire regulatory or voluntary carbon registry approval process would not have to start from the beginning for each new crop-location-geography combination. For example, if a protocol was developed for corn based on nitrogen rate reduction in the US Midwest, the first step would be to establish a 'corn' module, defining the crop. Then, a 'place' module would be developed to define the location and eligibility. Finally, a 'practice' module would be developed for the practice. To expand an overarching umbrella protocol to include corn grown in the Southeast, the corn module would be expanded upon to establish the necessary parameters for the geography and practices, without needing to develop all regulatory language and crop modules again.

Below we provide guidance on how, from a policy and regulatory perspective, the umbrella protocol could be initially developed and how additional modules for specific crops, places and practices could be developed and integrated under this umbrella. This policy perspective is based on consideration of both the current rice (ARB, 2015a) and forestry protocols (ARB, 2015b) approved by the California ARB, as well as an understanding of the policy process required for the development of a protocol.

\subsection{The umbrella protocol framework}

The initial umbrella protocol would lay out factors that are required for all protocols, but would be constant, regardless of the crop, geography or practice. By establishing these factors upfront, time is reduced in developing individual definitions at the start of every new crop, place, and practice module. We envision that the general umbrella protocol would be subject to the same regulatory and public comment processes as is typical of any protocol approval, but that the subsequent modules for additional crops, geographies or practices could be adopted through a streamlined process. It is important to note that the umbrella protocol is not in any way meant to supersede the scientific process for understanding, quantifying and modeling nitrogen rate reductions in $\mathrm{N}_{2} \mathrm{O}$ emissions resulting from changes in management; rather, the policy process can move forward in tandem with science. Like the scientific process, policy development also takes considerable time to refine and implement, often through many actors and influencing parties (Sabatier \& Weible, 2014).

Our proposed umbrella protocol would include the following sections:

1. Purpose and Definitions. Basic definitions would include those relevant to any agricultural protocol (e.g. 'baseline period', 'calibration', 'model parameter', etc.) as well as those specific to nitrogen management.

2. Eligibility. This would include general eligibility requirements, information regarding offset project operators and authorized project designees, general additionality clauses, offset project commencement, regulatory compliance, and project crediting period (assuming they are the same for all nitrogen practices).

3. GHG Assessment Boundary. This would set out the specific emissions included in the protocol (e.g. 'indirect vs direct emissions') and their sources, sinks, and reservoirs.

4. Monitoring. This would include all the monitoring parameters independent of crop, geography or practice that are generally accepted definitions (e.g. 'field location', 'daily precipitation', 'soil pH', 'planting date', etc.) as well as requirements for document retention by farmers and project developers.

5. Reporting. This would include requirements for both the general project listing and the offset project data report.

6. General Verification Requirements. This would include the required methods for verification, including any reporting mechanisms and reporting requirements. 


\subsection{Development of additional modules}

Following the adoption of an umbrella protocol, the protocol could be augmented in the future with additional modules, which could go through an abbreviated public comment and workshop process as the core parts of the protocol would be based on the already-approved umbrella protocol. We would anticipate three additional types of modules as shown in Figure 1: for crop, place, and practice - each of which is described in more detail below.

\subsubsection{Crop modules}

Crop modules would likely be the easiest to implement as these would describe definitions related to a crop and its production practices. These crop modules would be general enough to demonstrate legally what is meant by the crop in question. For example, in the ARB rice protocol, a rice field is defined as:

'... a contiguous parcel of land with homogeneous management on which rice is grown semi-continuously (i.e. at least one out of the last three cultivation years). A rice field usually has one water source inlet and one outlet and is usually separated into checks inside of perimeter levees that delineate the field's boundaries'.

This definition of a rice field does not change between rice grown in California or the Southeast. Hence, this crop module could be developed and approved once, and then utilized by future protocols.

\subsubsection{Place modules}

Place modules would incorporate the definitions of 'location' typically found in a protocol as well as provide clarification on eligibility requirements as determined by the location for which quantification methodologies have been calibrated and validated. Farmer and participant eligibility for this location would also need to be set forth. The place module would exist from a purely definitional standpoint and would stand alone irrespective of the practice. In other words, a place module developed for California would define the boundaries of California and which farmers and participants are eligible (i.e. farmers in California). Thus, once a module for a given place was developed, it could be utilized by future protocols for different crops and practices within the same given region.

\subsubsection{Practice modules}

Finally, the practice module (likely the most complex module in the framework) would flow specifically from the crop and location modules. For example, separate practice modules would be necessary for nitrogen rate reduction in corn in California and for corn in Nebraska, since the different climate, topography and soils would likely influence management practices, and thus a separate calibration and validation of $\mathrm{N}_{2} \mathrm{O}$ emission quantification methodologies for the combination of crop, location, and practice would be necessary. While both of these would utilize the same 'corn' module (because corn is defined as the same type of crop), they would have different 'place' modules for California and Nebraska, and different 'practice' modules flowing from their respective 'place' modules. Likewise, if a protocol for nitrogen rate reduction (practice) for leafy greens (crop) in California (place) had already been developed, and new scientific advances supported the development of a practice module for nitrification inhibitors in leafy greens in California, a module could be developed utilizing the already approved crop (leafy greens) and place (California) modules, with only the new practice module needing to be approved. Thus, while the initial development of both the umbrella protocol and first crop and location modules may be time consuming, in the future, these established modules could provide the baseline for faster inclusion of new management practices into a protocol where definitions and other legal and regulatory aspects have been pre-determined.

Note that, because the methodology to be used for quantifying GHG emission reductions is included in the practice module, rather than the umbrella protocol, this provides the protocol developer with the flexibility to select the most appropriate quantification methodology for a specific crop-location-management combination. Thus, the main component of the practice module is the detailed quantification methodology(ies) for the croplocation- management combination. 


\section{Best practices for practice modules based on best available science}

The practice module is where the fundamental scientific basis for proposed emission reductions, the suitability of various methodologies to quantify those emissions reductions, and various policy requirements must all be integrated and discussed. To ensure that practice modules are based on the best available science, while retaining the flexibility to update practice modules as scientific understanding and methodology development advance, we propose implementing a set of quantification 'best practices' as described in Tonitto et al., 2018. The key scientific underpinnings of any practice module are: (1) the strength of the evidence that a particular management practice consistently reduces $\mathrm{N}_{2} \mathrm{O}$ emissions, and (2) the selection of the most appropriate methodology to quantify emissions reductions from the given practice.

\subsection{Assessing whether a specific management practice consistently reduces $\mathrm{N}_{2} \mathrm{O}$ emissions}

The critical first step in development of a practice module is to ensure that there is both theoretical and empirical support that a given practice in a certain location and cropping system will reduce $\mathrm{N}_{2} \mathrm{O}$ emissions (Tonitto et al., 2018; Venterea et al., 2012). If scientific consensus has not been reached on this, then a practice module is not able to be developed and additional field data on practice performance must be collected. Currently, for a large number of common agricultural management practices, the results of field studies on their impacts on $\mathrm{N}_{2} \mathrm{O}$ emissions are often inconsistent, and indeed sometimes contradictory from one location to another and across years at any given location. Such variability can arise from inconsistency in sampling and measurement techniques, variability in the length of the study, as well as large intrinsic spatial (i.e. 'hot spots') and temporal variability (i.e. 'hot moments') in the processes which give rise to $\mathrm{N}_{2} \mathrm{O}$ emissions (Butterbach-Bahl, Baggs, Dannenmann, Kiese, \& Zechmeister-Boltenstern, 2013; McClain et al., 2003).

For example, field studies have variously shown that conversion to no-till or conservation tillage can increase, decrease or have very little impact on $\mathrm{N}_{2} \mathrm{O}$ emissions (Garland, Suddick, Burger, Horwath, \& Six, 2011; Kallenbach, Horwath, Kabir, Mitchell, \& Rolston, 2006; Kennedy, 2012; Lee et al., 2009). In a global meta-analysis, Six et al. (2004) found that $\mathrm{N}_{2} \mathrm{O}$ emissions were higher in the first few years after conversion to conservation-tillage. Significant $\mathrm{N}_{2} \mathrm{O}$ emission reductions in no till or conservation tillage systems were only realized after long term ( $>10$ years) implementation of these practices (Van Kessel et al., 2013). Furthermore, complications arise when a practice leads to a reduction in one greenhouse gas, such as carbon, but increases another greenhouse gas such as $\mathrm{N}_{2} \mathrm{O}$ (Li, Frolking, \& Butterbach-Bahl, 2005). Li et al., 2005, found that increasing carbon stocks in arable soils coincided with an increase in $\mathrm{N}_{2} \mathrm{O}$ emissions due to the strong link between carbon and nitrogen microbially mediated cycles.

Thus, the most important questions to address prior to practice module development are whether a consensus has been reached from currently available studies showing a consistent (downward) directional trend in $\mathrm{N}_{2} \mathrm{O}$ emissions from the given practice implementation in the given environmental conditions of the region in question, and whether that practice leads to a different negative environmental externality (i.e. nitrate leaching to groundwater or surface water bodies). This has been done by the Climate Action Reserve through a Science Advisory Committee which helped 'the Reserve interpret and apply the best available science into the Nitrogen Management Project Protocol' (Climate Action Reserve, 2011). We recommend this best practice be included in the process. If the answer to either question is ' $\mathrm{No}^{\prime}$, a practice module cannot be developed until adequate directional trends are established. For similar climates, geographical regions, and soil types, replicate studies must exist showing the consistent direction of emission reductions from a given practice. However, we hesitate to make a recommendation for the threshold on the number of studies that would be required to adopt a new practice module into the umbrella protocol, as this will be related to the level of uncertainty the relevant entity and peer review process is willing to accept, and ultimately should be decided by these parties.

\subsection{Selecting appropriate methodologies to quantify $\mathrm{N}_{2} \mathrm{O}$ emissions reductions from practice implementation}

Assuming that there is scientific consensus that a given practice consistently reduces $\mathrm{N}_{2} \mathrm{O}$ emissions, attention then can turn to reviewing potential quantification methodologies. A wide variety of quantification tools are 
available and the choice of model is important for accurately quantifying reductions (Denef, Paustian, Archibeque, Biggar, \& Pape, 2012; Tonitto et al., 2018) (Table 2).

A methodology for selecting the most appropriate quantification methodology has recently been published by Tonitto et al. (2018) and we direct the reader to that publication for additional details. In particular, we draw attention to the sections in Tonitto et al. (2018) on (i) assessing whether the model has been appropriately calibrated and validated for the crop, soil type, climate, and practice of interest, (ii) evaluating whether the model is a good match to policy constraints such as risk tolerance and the availability of modeling resources, (iii) documenting the specifics of how a model is to be used in a specific protocol and (iv) conducting peer review of model selection, use and outputs.

From the work by Tonitto et al. (2018), it is important to highlight that models are only valid for the region in which they are developed or for areas that have substantially similar climates, soils, cropping systems, and management practices. A separate validation using field studies or high-quality field datasets should be conducted when applying models to a new region (Paustian et al., 2016). Furthermore, models are limited in their ability to estimate combinations of management practices unless the model has been specifically developed for combined management strategies (Olander \& Haugen-Kozyra, 2011).

Regardless of the choice of quantification methodology, an uncertainty analysis must be conducted to understand the overall accuracy of the model. Uncertainty arises from measurement error, variation in the data, limitations in input data, inaccuracy of the model to describe the underlying biogeochemical processes, and approximation error (simplistic representation of the underlying processes) (Del Grosso, Ahuja, \& Parton, 2016; Tonitto et al., 2018).

Recently, a spatial framework has been developed for scaling up technologies and increasing the efficiency and rate of technology transfer by delineating 'technology extrapolation domains' (TED) based on similar biophysical characteristics across geographically separated areas (Edreira Rattalino et al. 2018). TEDs are useful for determining the minimum amount and spatial distribution needed to accurately capture the variability in yield and environmental performance and extrapolating results to similar TEDs across regional, national and global scales and could conceivably be considered in an $\mathrm{N}_{2} \mathrm{O}$ protocol. Edreira Rattalino et al. (2018) were successful

Table 2. Some common agricultural $\mathrm{N}_{2} \mathrm{O}$ quantification methodologies.

\begin{tabular}{|c|c|c|c|}
\hline $\begin{array}{l}\text { Quantification } \\
\text { Methodology }\end{array}$ & Developers & Methodology Type & Implementation \\
\hline COMET-Farm & $\begin{array}{l}\text { Colorado State } \\
\text { University (2016), USDA, } \\
\text { and NRCS }\end{array}$ & $\begin{array}{l}\text { combined process based models - DNDC } \\
\text { and DAYCENT }\end{array}$ & $\begin{array}{l}\text { NRCS Greenhouse Gas Accounting Tool } \\
\text { for Government Sponsored } \\
\text { Conservation initiatives }\end{array}$ \\
\hline DAYCENT & $\begin{array}{l}\text { Natural Resources Ecology } \\
\text { Laboratory, Colorado State } \\
\text { University }\end{array}$ & process based model & $\begin{array}{l}\text { Informing the development of the } \\
\text { Climate Action Reserve Nitrogen } \\
\text { Management Protocol Version } 2.0\end{array}$ \\
\hline DNDC & University of New Hampshire & process based model & $\begin{array}{l}\text { American Carbon Registry Changes } \\
\text { Fertilizer Management Protocol to } \\
\text { Reduce } \mathrm{N}_{2} \mathrm{O} \text { Emissions Version } 2.1\end{array}$ \\
\hline $\begin{array}{l}\text { USDA Greenhouse } \\
\text { Gas Quantification } \\
\text { Methodology }\end{array}$ & USDA & $\begin{array}{l}\text { Mixed process-based and empirical } \\
\text { model (Paustian et al., 2004; Snyder, } \\
\text { Bruulsema, \& Jensen, 2007, 2009; } \\
\text { Robertson \& Vitousek, 2009; Akiyama, } \\
\text { Yan, \& Yagi, 2010; Ogle, Archibeque, } \\
\text { Gurung, \& Paustian, 2010; T-AGG, 2010) } \\
\text { methodology published by Ogle et al., } \\
\text { 2014; summarized in Denef, } \\
\text { Archibeque, \& Paustian, 2011. }\end{array}$ & $\begin{array}{l}\text { Informing the development of the } \\
\text { Climate Action Reserve Nitrogen } \\
\text { Management Protocol Version } 2.0\end{array}$ \\
\hline MSU-EPRI & $\begin{array}{l}\text { Michigan State University and } \\
\text { the Electric Power Research } \\
\text { Institute (2015) }\end{array}$ & empirical model & $\begin{array}{l}\text { American Carbon Registry Reduced } \\
\text { Fertilizer Use Version 1.0, Climate } \\
\text { Action Reserve Nitrogen Management } \\
\text { Protocol Version 1.1, Verified Carbon } \\
\text { Standard VM0022 Quantifying } \mathrm{N}_{2} \mathrm{O} \\
\text { Emissions Reductions in Agricultural } \\
\text { Crops through Nitrogen Fertilizer Rate } \\
\text { Reduction, v1.1 }\end{array}$ \\
\hline
\end{tabular}


in creating a TED framework that accurately captured the variability in crop yield and yield stability for rainfed corn systems across domains that have similar climatic (annual growing degree days, aridity index, annual temperature seasonality) and soil factors (plant available water holding capacity). They were able to apply the framework to double cropping, a technology commonly practiced in Chile, however rarely practiced in Australia. They found that across similar TEDs in both countries, double cropping improved incomes for Australian farmers, demonstrating successful technology transfer. While this approach is promising, developing a TED framework requires high quality data with sufficient spatial coverage and resolution, and validation of the ability of a TED framework to accurately predict the yield or environmental outcome. Furthermore, for $\mathrm{N}_{2} \mathrm{O}$ emissions, additional biophysical and socioeconomic factors (output and input prices, farm size, access to markets, credit, legislation, and information) beyond climatic and soil factors used in the aforementioned TED would have to be considered given the complexity of processes affecting $\mathrm{N}_{2} \mathrm{O}$ production.

\subsection{A suggested process for developing a practice module}

Figure 2 below contextualizes the best practices for model validation (Tonitto et al., 2018) into a policy context, demonstrating our suggested process for developing a practice module.

The first stage, Practice Performance, requires a review of the literature to determine whether there is strong theoretical and empirical support for quantifiable environmental benefits from a specific management practice.

The second stage, Model Availability and Validation, involves determining if a potential quantification tool has been appropriately validated for the specific region, climate, soil texture, cropping system and management practices under study.

The third stage, Model Selection, which would typically involve an uncertainty analysis, requires considering whether the proposed quantification methodology aligns with the risk tolerance (level of accuracy required for model results) and implementation resources available to protocol developers and policymakers.

The fourth stage, Model Documentation and Peer Review, requires thorough documentation of how the model was used, including the model version and chosen input parameters; this documentation is crucial to enabling others to replicate model outputs. By peer review process, we do not necessarily mean publication of model specifics in a peer-reviewed journal (though we note that this has been done for the protocol based on the MSU-EPRI model, (Millar et al., 2010)). Rather, we mean the convening of a group of experts, such as the Climate Action Reserve did for their Nitrogen Management Project Protocol (Climate Action Reserve, 2011), to include researchers familiar with the field studies of changes in $\mathrm{N}_{2} \mathrm{O}$ emissions resulting from practice implementation and the developers of the underlying quantification methodology, together with a number of independent scientific experts, to review the rationale for model selection, the documentation of model use, and the credibility of model results. The discussions and conclusions of this group should be reported, summarized and made available for broader public comment before a practice module can be approved.

The fifth stage, Practice Module, represents the conclusion of the assessment of the scientific defensibility of the module. Once a module reaches this stage, the other necessary components, such as assessment boundaries and reporting conditions, can be developed and submitted for approval.

Although the fifth stage may appear to be the final stage in the process, we recognize that scientific understanding of $\mathrm{N}_{2} \mathrm{O}$-generating processes will continue to advance, that additional datasets will become available to improve model calibration and validation, and that new quantification methodologies will be developed. We recommend, therefore, that practice modules be reviewed on a regular basis to determine whether there is a need for revision and updating. We anticipate that such revision and updating would follow the same sequence as shown in Figure 2.

\section{Current and future opportunities for practice modules}

At present, the only nitrogen management practice that is widely accepted to reduce $\mathrm{N}_{2} \mathrm{O}$ emissions is reduction of $\mathrm{N}$ application rate (Eve et al., 2014). However, our umbrella protocol envisions developing distinct nitrogen rate reduction modules for different crops in different locations. With an eye towards the future, we have specifically aimed to develop this framework such that other management practices could be included. These practices 


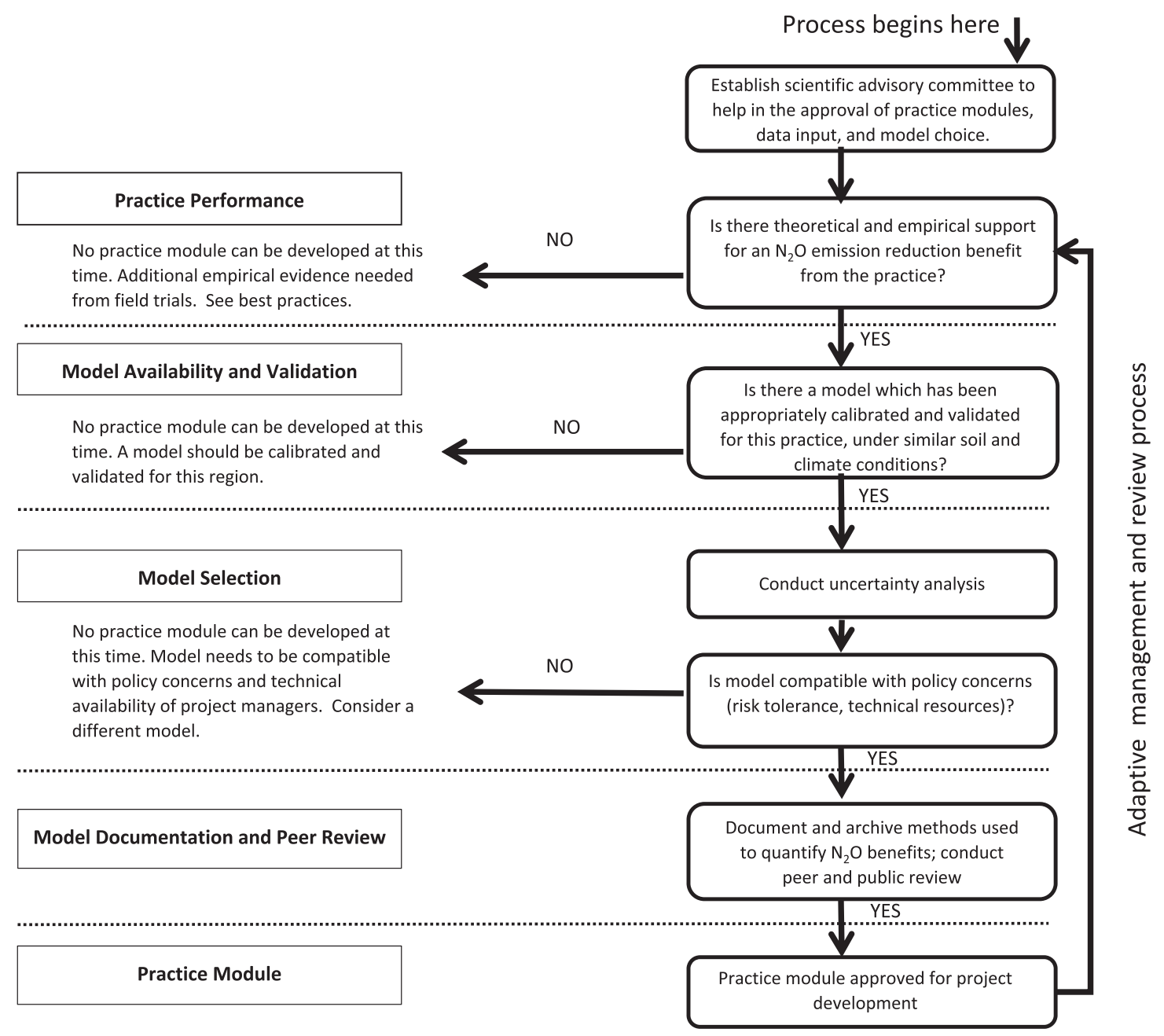

Figure 2. Suggested Process for Developing a Scientifically-Defensible Practice Module, process adapted from Tonitto et al 2018.

would work their way through the framework in the same manner that we propose $\mathrm{N}$ rate could do, by first assessing the availability of data specific to practices. As the future body of work in these other $\mathrm{N}$ management strategies continues, it is likely that this umbrella protocol could be expanded to include these different practices. However, as suggested in Figure 1, the addition of new management practices would require new modules to be adopted by the regulatory body that approved the original umbrella protocol.

Furthermore, since the interaction of multiple practices can have significant impact on $\mathrm{N}_{2} \mathrm{O}$ emissions (Halvorson, Del Grosso, \& Alluvione, 2010; Kallenbach, Rolston, \& Horwath, 2010; Waterhouse, Wade, Horwath, \& Burger, 2017), and since the effect on $\mathrm{N}_{2} \mathrm{O}$ emissions of these practices cannot be assumed to be additive, it will be necessary that each combination of practices (i.e. $\mathrm{N}$ rate reduction and nitrification inhibitors) is covered by its own module. For example, Halvorson et al. (2010) found that an enhanced efficiency fertilizer (polymer-coated urea) had no effect on emissions in the conventional tillage system, but did reduce emissions in the no-till system, implying an interaction of tillage system and fertilizer source. This also means that each combination of practices will need to be supported by field data, and an appropriate model capable of representing the impact of these combined practices identified, before a module can be developed. For example, even if data on $\mathrm{N}$ rate reduction and nitrification inhibitors exist for the same crop and location (but the studies were conducted separately), a new dataset would be required examining the combined effects of $\mathrm{N}$ rate reduction and nitrification inhibitors on $\mathrm{N}_{2} \mathrm{O}$ emissions, and either an empirical model would need to be 
developed based on this data or sufficient data would need to exist to calibrate and validate a process-based model. While creating modules for interactions that stand alone and are separate from the two individual modules seems onerous, this is an opportunity for further research.

\section{Additional considerations}

\subsection{Adaptive management and science policy communication}

The umbrella protocol and practice module frameworks we developed here draw upon our diverse and complementary backgrounds in biophysical, natural, social and policy sciences to consider both the natural and social sciences as well as the policy context in which nitrogen management protocols are developed. We believe that for a protocol of this nature to be implemented and to succeed, an adaptive management framework (Williams, 2011 ) is necessary and clear science-policy communication is needed. Throughout the umbrella protocol framework we have identified points in which the policy sphere is able to communicate to scientists about the appropriate data needed for the integration of additional modules, and about opportunities to evolve the protocol to include future best practices to shift with a tide of research. Simultaneously, we believe that it will be necessary for the policy sphere to adjust and adapt to given constraints, such as those typical of funding cycles. While three or more years of data collection for a particular scientific study would be optimal for a protocol, it may not be feasible in reality. In situations in which this is not achieved, it highlights the continued importance of adaptive management, in which protocols can be reviewed in a timely manner when new data become available and be updated accordingly. This continued dialogue between scientists and policymakers, and the evolution of the protocol as new data or policy resources become available, can enable the inclusion of future management practices, best scientific practices, and new tools and quantification options.

\subsection{Farmer adoption and participation}

Ultimately a protocol is only successful if a farmer actually participates. Thus, it is crucial to consider the factors that will affect farmer adoption of nitrogen management practices and to balance these perspectives in the development of a protocol. While a thorough review of the literature on farmer adoption of nitrogen management practices is outside the scope of this article, we want to note a few important factors for consideration.

First, not all nitrogen management practices should be considered equally when it comes to how farmers view them and their potential adoption. For example, among California farmers, ' $\mathrm{N}$ rate efficiency' is far more likely to be adopted than nitrogen rate reduction (Haden, Niles, Lubell, Perlman, \& Jackson, 2012; Niles, Lubell, Haden, \& Jackson, 2013), perhaps because a focus on $\mathrm{N}$ rate reduction risks jeopardizing yield, whereas a focus on Nitrogen Use Efficiency (NUE) accounts for both fertilizer inputs and yield outputs, which is much more appealing to farmers. Thus protocols which take account of farmers' dual concerns about fertilizer use and yield may be more likely to be adopted. While there is limited data to support a relationship between NUE and $\mathrm{N}_{2} \mathrm{O}$ emissions (Omonode, Halvorson, Gagnon, \& Vyn, 2017), there is robust evidence of a relationship between $\mathrm{N}$ balance (nitrogen inputs minus nitrogen outputs) and $\mathrm{N}_{2} \mathrm{O}$ emissions (McLellan et al., 2018; Omonode et al., 2017). Thus creating a protocol based on $\mathrm{N}$ balance, rather than $\mathrm{N}$ rate reduction, may provide a way to reconcile natural and biophysical scientific insight into ways to reduce $\mathrm{N}_{2} \mathrm{O}$ emissions with social science data suggesting that management strategies which account for yield may be preferable to farmers. However, care should be given to the $\mathrm{N}$ balance approach since many factors outside the farmer's control can affect $\mathrm{N}$ uptake (or $\mathrm{N}$ outputs), such as drought or disease, making $\mathrm{N}$ vulnerable to loss as $\mathrm{N}_{2} \mathrm{O}$ emissions, which could lead to emissions offset credit reductions. Furthermore, such a change to current protocols (all currently based on $\mathrm{N}$ rate reduction) would require a change in verification of this approach at the farm level.

Second, predicting farmer adoption of practices is exceptionally challenging. For example, even when using variables that social theories would traditionally suggest drive farmer adoption of nitrification inhibitors (age, farm income, farmer education, perception of practice on water quality, participation in government programmes), these factors only predicted $9 \%$ of the adoption variance (Robinson \& Napier, 2002). One of the reasons that this prediction is so challenging is that the factors that influence a farmer's potential adoption of 
a climate mitigation strategy (e.g. climate change belief perceptions) are very different than the factors that influence their actual adoption of those same strategies (e.g. perceived capacity to mitigate) (Niles, Brown, \& Dynes, 2016). Thus, if research only asks farmers about their likelihood to do something as a method of predicting farmer adoption, they will likely overlook other important factors.

Finally, and critical for the development of a carbon offset protocol, farmers may be adopting these practices for a variety of reasons, which may not be motivated by the market itself. This is especially important to consider for nitrogen management strategies since many existing government programmes, including the Environmental Quality Incentives Program (EQIP) and the Conservation Stewardship Program (CSP), include a number of nitrogen management strategies, though this varies according to state priorities (USDA NRCS, 2017). A farmer must express some level of interest or intention in carbon market participation as motivation for undertaking improved nitrogen management strategies in order to be considered as an eligible market participant. Farmers cannot claim credits without such an attestation, especially if they have been receiving government payments for the practices for multiple years before applying for credits.

\section{Conclusion}

Reducing $\mathrm{N}_{2} \mathrm{O}$ emissions in agricultural systems is complex. These emissions are highly variable depending on soil, climate, crop and management systems. As a result, developing protocols for inclusion in a carbon offset market to reduce $\mathrm{N}_{2} \mathrm{O}$ emissions cannot be one-size-fits-all. This reality is one reason why the adoption of such protocols has been slow, and their potential expansion has been limited. Here, we aim to develop a framework for how an umbrella protocol for nitrogen rate reduction could be developed, which can ultimately be applied for other nitrogen management strategies as well. We have developed an approach that would provide the basis for developing an umbrella protocol with basic definitions, with opportunity to develop crop, place and practice modules as data becomes available.

We also highlight here a number of the social science aspects of protocol development and adoption (mainly farmer adoption and willingness to participate in the protocol) that we acknowledge are largely outside the scope of this report. Nevertheless, we believe that through an umbrella protocol we can harness the best available science and apply it through an adaptive framework to develop an umbrella $\mathrm{N}$ protocol that can cover many crops, locations and practices.

\section{Notes}

1. For example, through the Climate Action Reserve and American Carbon Registry databases of projects, only two have been listed for $\mathrm{N}_{2} \mathrm{O}$ reduction from agriculture (both at American Carbon Registry) despite protocols having been adopted since November 2010.

2. The first technical working group meeting of the rice protocol was held on 10 May 2013 (https://www.arb.ca.gov/cc/ capandtrade/protocols/riceprotocol.htm). The Board voted on the final protocol on 25 June 2015 (https://www.arb.ca.gov/ board/ma/2015/ma062515.pdf)

\section{Acknowledgements}

This project was supported by the U.S. Department of Agriculture's Natural Resource Conservation Service through a Conservation Innovation Grant overseen by the Environmental Defense Fund. We thank Amy Hughes for her review and helpful feedback on our manuscript. Additional technical support was provided by Peter Woodbury and Christine Tonitto of Cornell University.

\section{Disclosure statement}

No potential conflict of interest was reported by the authors.

\section{Funding}

This work was supported by U.S. Department of Agriculture [Conservation Innovation Grant]. 


\section{References}

Air Resources Board (ARB). (2015a). Compliance offset protocol rice cultivation projects. California Environmental Protection Agency. https://www.arb.ca.gov/cc/capandtrade/protocols/rice/riceprotocol2015.pdf

Air Resources Board (ARB). (2015b). Compliance offset protocol U.S. forest projects. California Environmental Protection Agency. https://www.arb.ca.gov/cc/capandtrade/protocols/usforest/forestprotocol2015.pdf

Air Resources Board (ARB). (2017). Compliance offset program. California Environmental Protection Agency. Accessed August $9,2017$. https://www.arb.ca.gov/cc/capandtrade/offsets/offsets.htm

Akiyama, H., Yan, X., \& Yagi, K. (2010). Evaluation of effectiveness of enhanced-efficiency fertilizers as mitigation options for $\mathrm{N}_{2} \mathrm{O}$ and NO emissions from agricultural soils: Meta-analysis. Global Change Biology, 16(6), 1837-1846.

Butterbach-Bahl, K., Baggs, E. M., Dannenmann, M., Kiese, R., \& Zechmeister-Boltenstern, S. (2013). Nitrous oxide emissions from soils: How well do we understand the processes and their controls? Philosophical Transactions of the Royal Society B: Biological Sciences, 368, 20130122.

Cassman, K. G., Dobermann, A., \& Walters, D. T. (2002). Agroecosystems, nitrogen-use efficiency, and nitrogen management. AMBIO: A Journal of the Human Environment, 31, 132-140.

Climate Action Reserve. (2011). Nitrogen Management Project Protocol Development. http://www.climateactionreserve.org/how/ protocols/nitrogen-management/dev/\#

Colorado State University. (2016). COMET-Farm Tool. http://cometfarm.nrel.colostate.edu/

Del Grosso, S. J., Ahuja, L. R., \& Parton, W. J. (2016). Modeling GHG emissions and carbon changes in agricultural and forest systems to guide mitigation and adaptation: Synthesis and future needs. In S. Del Grosso, L. Ahuja, \& W. Parton (Eds.), Synthesis and modeling of greenhouse gas emissions and carbon storage in agricultural and forest systems to guide mitigation and adaptation, Adv. Agric. Syst. Model (Vol. 6, pp. 305-318). Madison, WI: ASA, CSSA, and SSSA.

Denef, K., Archibeque, S., \& Paustian, K. (2011). Greenhouse gas emissions from U.S. agriculture and forestry: A review of emission sources, controlling factors, and mitigation potential. Interim report to USDA under Contract \#GS23F8182H.

Denef, K., Paustian, K., Archibeque, S., Biggar, S., \& Pape, D. (2012). Report of greenhouse gas accounting tools for agriculture and forestry sectors. Interim report to USDA under Contract No. GS23F8182H.

Eagle, A. J., Olander, L. P., Henry, L. R., Haugen-Kozyra, K., Millar, N., \& Philip Robertson, G. (2010). Greenhouse gas mitigation potential of agricultural land management in the United States. A Synthesis of the Literature. Technical Working Group on Agricultural Greenhouse Gases (T-AGG) Report.

Edreira Rattalino, J. I., Cassman, K. G., Hochman, Z., van Ittersum, M. K., van Bussel, L., Claessens, L., \& Grassini, P. (2018). Beyond the plot: Technology extrapolation domains for scaling out agronomic science. Environmental Research Letters, $13,054027$.

Electrical Power Research Institute (EPRI). (2015). Background information on the MSU-EPRI Methodology for quantifying nitrous oxide emissions reductions from reduced use of nitrogen fertilizer on agricultural crops. Executive Summary. Available: http://extension. missouri.edu/sare/documents/Backgroundlnformation2012.pdf

Environmental Protection Agency. (2015) Inventory of U.S. greenhouse gas emissions and sinks: 1990-2013.

Eve, M., Pape, D., Flugge, M., Steele, R., Man, D., Riley-Gilbert, M., \& Biggar, S. (Eds.). (2014). Quantifying greenhouse gas fluxes in agriculture and forestry: Methods for entity-scale inventory. Technical bulletin number 1939 (p. 606). Washington, DC: Office of the Chief Economist, U.S. Department of Agriculture.

Garland, G. M., Suddick, E., Burger, M., Horwath, W. R., \& Six, J. (2011). Direct $\mathrm{N}_{2} \mathrm{O}$ emissions following transition from conventional till to No-till in a cover-cropped mediterranean vineyard (Vitis Vinifera). Agriculture, Ecosystems \& Environment, 144(1), 423-428.

Haden, V. R., Niles, M. T., Lubell, M., Perlman, J., \& Jackson, L. E. (2012). Global and local concerns: What attitudes motivate farmers to mitigate and adapt to climate change. PLoS One, 7, doi:10.1371/journal.pone.0052882

Halvorson, A. D., Del Grosso, S. J., \& Alluvione, F. (2010). Tillage and inorganic nitrogen source effects on nitrous oxide emissions from irrigated cropping systems. Soil Science Society of America Journal, 74(2), 436.

Henault, C., Grossel, A., Mary, B., Roussel, M., \& Leonard, J. (2012). Nitrous oxide emission by agricultural soils: A review of spatial and temporal variability for mitigation. Pedosphere, 22, 426-433. doi:https://doi.org/10.1016/S1002-0160(12)60029-0

IPCC. (2014). Climate change 2014: Synthesis report. Contribution of working groups I, II and III to the fifth assessment report of the intergovernmental panel on climate change. Core Writing Team, R. K. Pachauri \& L. A. Meyer (Eds.), (p. 151). Geneva, Switzerland: IPCC.

Kallenbach, C., Horwath, W. R., Kabir, Z., Mitchell, J., \& Rolston, D. (2006). Use of conservation tillage, subsurface drip irrigation and cover cropping to reduce soil carbon and nitrogen emissions and sequester soil carbon. University of California, Davis: Kearney Foundation of Soil Science. http://kearney.ucdavis.edu/OLD\%20MISSION/2004_Final_Reports/2004221Horwath_ FINALkms.pdf

Kallenbach, C. M., Rolston, D. E., \& Horwath, W. R. (2010). Cover cropping affects soil $\mathrm{N}_{2} \mathrm{O}$ and $\mathrm{CO}_{2}$ emissions differently depending on type of irrigation. Agriculture, Ecosystems \& Environment, 137(3-4), 251-260.

Kennedy, T. L. (2012). Nitrous oxide emissions from california tomato cropping systems under conventional and alternative management. M.S., University of California, Davis.

Lee, J., Hopmans, J. W., van Kessel, C., King, A. P., Evatt, K. J., Louie, D., ... Six, J. (2009). Tillage and seasonal emissions of $\mathrm{CO}_{2}$, $\mathrm{N}_{2} \mathrm{O}$ and NO across a seed bed and at the field scale in a Mediterranean Climate. Agriculture, Ecosystems \& Environment, 129(4), 378-390. 
Li, C., Frolking, S., \& Butterbach-Bahl, K. (2005). Carbon sequestration in arable soils is likely to increase nitrous oxide emissions, offsetting reductions in climate radiative forcing. Climatic Change, 72, 321.

McClain, M. E., Boyer, E. W., Dent, C. L., Gergel, S. E., Grimm, N. B., Groffman, P. M., .. Pinay, G. (2003). Biogeochemical hot spots and hot moments at the interface of terrestrial and aquatic ecosystems. Ecosystems, 6, 301-312.

McLellan, E. L., Cassman, K. G., Eagle, A. J., Woodbury, P. B., Sela, S., Tonitto, C., ... van Es, H. M. (2018). The nitrogen balancing act: Tracking the environmental performance of food production. BioScience, 68(3), 194-203.

Millar, N., Robertson, G. P., Diamant, A., Gehl, R. J., Grace, P. R., \& Hoben, J. P. (2012). Methodology for Quantifying Nitrous Oxide (N ${ }_{2} \mathrm{O}$ ) Emissions Reductions by Reducing Nitrogen Fertilizer Use on Agricultural Crops. American Carbon Registry, Winrock International, Little Rock, Arkansas.

Millar, N., Robertson, G. P., Grace, P. R., Gehl, R. J., \& Hoben, J. P. (2010). Nitrogen fertilizer management for nitrous oxide ( $\left.\mathrm{N}_{2} \mathrm{O}\right)$ mitigation in intensive corn (Maize) production: An emissions reduction protocol for US midwest agriculture. Mitigation and Adaptation Strategies for Global Change, 15(2), 185-204.

Niles, M. T., Brown, M., \& Dynes, R. (2016). Farmer's intended and actual adoption of climate change mitigation and adaptation strategies. Climatic Change, 135, 277-295.

Niles, M. T., \& Lubell, M. (2012). Integrative frontiers in environmental policy Theory and research. Policy Studies Journal, 40, 41-64.

Niles, M. T., Lubell, M., Haden, R., \& Jackson, L. (2013). Managing for climate change in agriculture: Farmer adoption of practices. A Policy Brief from The Center for Environmental Behavior and Policy. University of California, Davis. http://environmentalpolicy. ucdavis.edu/files/cepb/Yolo_Climate_Practices_Policy_Brief_FINAL_2.pdf

Ogle, S. M., Adler, P. R., Breidt, F. J., Del Grosso, S., Derner, J., Franzluebbers, A., ... West, T. (2014). Chapter 3: Quantifying Greenhouse Gas Sources and Sinks in Cropland and Grazing Land Systems. In Quantifying Greenhouse Gas Fluxes in Agriculture and Forestry: Methods for Entity-Scale Inventory. Technical Bulletin Number 1939. Office of the Chief Economist, U.S. Department of Agriculture, Washington, DC. 606 pages. July 2014. Eve, M., D. Pape, M. Flugge, R. Steele, D. Man, M. Riley-Gilbert, and S. Biggar, Eds.

Ogle, S. M., Archibeque, S. L., Gurung, R., \& Paustian, K. (2010). Report on GHG mitigation literature review for agricultural systems: Submitted to USDA climate change office.

Olander, L. P., \& Haugen-Kozyra, K. (2011). Using biogeochemical process models to quantify greenhouse gas mitigation from agricultural management projects. Technical Working Group on Agricultural Greenhouse Gases (T-AGG) Supplemental Report. Duke Nicholas Institute for Environmental Policy Solutions.

Omonode, R. A., Halvorson, A. D., Gagnon, B., \& Vyn, T. J. (2017). Achieving lower nitrogen balance and higher nitrogen recovery efficiency reduces nitrous oxide emissions in North America's Maize cropping systems front. Plant Science, 8, 1080.

Paustian, K., Babcock, B. A., Hatfield, J. L., Lal, R., McCarl, B. A., McLaughlin, S., ... Zilberman, D. (2004). Climate change and greenhouse gas mitigation challenges and opportunities for agriculture. Ames, IA: Council on Agricultural Science and Technology (CAST).

Paustian, K., Lehmann, J., Ogle, S., Reay, D., Robertson, G. P., \& Smith, P. (2016). Climate-smart soils. Nature, 532(7597), $49-57$.

Reay, D. S., Davidson, E. A., Smith, K. A., Smith, P., Melillo, J. M., Dentener, F., \& Crutzen, P. J. (2012). Global agriculture and nitrous oxide emissions. Nature Climate Change, 2, 410-416.

Rees, R. M. (2011). Global Nitrous Oxide Emissions: Sources and Opportunities for Mitigation. Understanding Greenhouse Gas Emissions from Agricultural Management American Chemical Society. 14-257.

Robertson, G. P., \& Vitousek, P. M. (2009). Nitrogen in agriculture: Balancing the cost of an essential resource. Annual Review of Environment and Resources, 34(97), 125.

Robinson, J. R., \& Napier, T. L. (2002). Adoption of nutrient management techniques to reduce hypoxia in the Gulf of Mexico. Agricultural Systems, 72, 197-213.

Sabatier, P., \& Weible, C. (2014). Theories of the policy process (3rd ed). Boulder, CO: Westview Press.

Shcherbak, l., Millar, N., \& Robertson, G. P. (2014). Global metaanalysis of the nonlinear response of soil nitrous oxide $\left(\mathrm{N}_{2} \mathrm{O}\right)$ emissions to fertilizer nitrogen. Proceedings of the National Academy of Sciences of the United States of America, 111(25), 9199-9204.

Six, J., Ogle, S. M., Breidt, F. J., Conant, R. T., Mosier, A. R., \& Paustian, K. (2004). The potential to mitigate global warming with no-tillage management Is only realized when practised in the long term. Global Change Biology, 10(2), 155-160.

Smith, P., Martino, D., Cai, Z., Gwary, D., Janzen, H., Kumar, P., ... Press, C. U. (2007). Climate Change 2007: Mitigation. Contribution of Working Group III for the Fourth Assessment Report of the Intergovernmental Panel on Climate Change. B. Metz, O. R. Davidson, P. R. Bosch, R. Dave, \& L. A. Meyer (Eds.). Agriculture Cambridge, United Kingdom and New York, NY.

Snyder, C. S., Bruulsema, T. W., \& Jensen, T. L. (2007). Greenhouse gas emissions from cropping systems and the influence of fertilizer management - A literature review: International plant nutrition institute (IPNI).

Snyder, C. S., Bruulsema, T. W., Jensen, T. L., \& Fixen, P. E. (2009). Review of greenhouse gas emissions from crop production systems and fertilizer management effects. Agriculture, Ecosystems \& Environment, 133(3-4), 247-266.

Tonitto, C., Woodbury, P., \& McLellan, E. L. (2018). Defining a best practice methodology for modeling the environmental performance of agriculture. Environmental Science and Policy, 87, 64-73.

USDA Natural Resources Conservation Service (NRCS). (2017). Environmental quality incentives program. https://www.nrcs.usda.gov/ wps/portal/nrcs/main/national/programs/financial/eqip/ 
Van Kessel, C., Venterea, R., Six, J., Adviento-Borbe, M. A., Linquist, B. A., \& van Groenigen, K. J. (2013). Climate, duration, and N placement determine $\mathrm{N}_{2} \mathrm{O}$ emissions in reduced tillage systems: A meta- analysis. Global Change Biology, 19(1), 33-44.

Venterea, R. T., Halvorson, A. D., Kitchen, N., Liebig, M. A., Cavigelli, M. A., Grosso, S. J., ... Collins, H. (2012). Challenges and opportunities for mitigating nitrous oxide emissions from fertilized cropping systems. Frontiers in Ecology and the Environment, 10, 562-570.

Waterhouse, H., Wade, J., Horwath, W. R., \& Burger, M. (2017). Effects of positively charged dicyandiamide and nitrogen fertilizer sources on nitrous oxide emissions in irrigated corn. Journal of Environmental Quality, 46, 1123-1130.

Williams, B. K. (2011). Adaptive management of natural resources_framework and issues. Journal of Environmental Management, 92, 1346-1353.

World Bank. (2017). Nitrous oxide emissions (2012 Data). http://data.worldbank.org/indicator/EN.ATM.NOXE.KT.CE 